\title{
Short Communication: Effect of Leptin Gene Polymorphisms on Breeding Value for Milk Production Traits
}

\author{
Z. Madeja, T. Adamowicz, A. Chmurzynska, T. Jankowski, J. Melonek, \\ M. Switonski, and T. Strabel \\ Department of Genetics and Animal Breeding, \\ August Cieszkowski Agricultural University of Poznan, Poland
}

\begin{abstract}
New molecular techniques focused on genome analysis open new possibilities for complex evaluation of economically important traits in farm animals. Milk production traits are typical quantitative characteristics controlled by a number of genes. Mutations in their sequences may alter animal performance as well as their breeding values. In this study, we investigated the effect of 3 restriction fragment length polymorphisms (RFLP): HphI, Kpn2I, and Sau3AI in the leptin gene, on bull breeding values for milk, fat, and protein yield, and fat and protein content. One hundred seventeen Polish Black and White AI bulls were genotyped. Pedigree analysis indicated a relatively close relationship between the bulls. Statistical analysis indicated that the $H p h \mathrm{I}$ polymorphism has a significant effect on milk and protein yield. Animals with the TT genotype had approximately $2 \times$ higher estimated breeding values for milk and protein yields. No effect was found for the other 2 polymorphisms.
\end{abstract}

(Key words: dairy cattle, leptin polymorphism, milk traits, breeding value)

Abbreviation key: BTA = Bos taurus autosome.

Milk production traits are quantitative traits controlled by numerous genes and environmental factors. Recent genome scans using Dairy Bull DNA Repository grandsire families found strong evidence for QTL on Bos taurus autosome (BTA) 3 (affecting protein and fat percentage), on BTA 6 (affecting protein and fat percentage), on BTA 14 (affecting fat percentage), and on BTA 20 (affecting protein percentage) (Ashwell et al., 2004). Lindersson et al. (1998) reported a QTL for milk production traits on chromosome 4 in a region where the leptin gene and the serum amylase- 1 gene are located. The leptin gene itself is considered a poten-

Received April 21, 2004.

Accepted August 26, 2004.

Corresponding author: Tomasz Strabel; e-mail: strabel@man. poznan.pl. tial QTL, influencing different production traits in cattle, for example, meat production (Buchanan et al., 2002), milk performance (Silva et al., 2002; Buchanan et al., 2003), and reproduction (Gonzalez et al., 2000). Several polymorphisms in this gene have been found. In exon 2, two RFLP were described: ClaI (an A/T substitution resulting in an AA change from tyrosine to phenylalanine) (Lagonigro et al., 2003), and Kpn2I (a $\mathrm{C} / \mathrm{T}$ substitution resulting in an AA change from arginine to cysteine) (Buchanan et al., 2002). Another 2 RFLP were identified in exon 3: NruI (a C/T substitution resulting in a change from valine to alanine) (Lagonigro et al., 2003), and HphI (a C/T substitution resulting in a change from alanine to valine) (Haegeman et al., 2000). Moreover, a Sau3AI polymorphism in intron 2 was found (Pomp et al., 1997). In addition, in the BovMap database (http://locus.jouy.inra.fr), 19 other single nucleotide polymorphisms are listed.

The aim of this study was to confirm a suggested influence of Kpn2I, HphI, and Sau3AI polymorphisms on milk production. Studies were performed on 117 Polish Black and White proven bulls with an average reliability of $93.2 \%$ (ranging from 71 to 99). Estimated breeding values for milk, fat, and protein yield, and fat and protein content from official Polish evaluations were used. Animal pedigrees used in this study were complete on the sire and dam side. Over $62 \%$ of the ancestors up to the seventh generation were known. DNA was extracted from blood using the phenol-chloroform method (according to standard protocol). For each PCR reaction (conditions specified in Table 1), $0.5 \mathrm{U}$ of Taq polymerase (Finnzymes, Espoo, Finland), $200 \mu \mathrm{M}$ of dNTP (Eppendorf, Hamburg, Germany), and $0.3 \mu \mathrm{M}$ of primer were used. The RFLP were analyzed as follows. For Kpn2I, a 94-bp PCR product was digested for $2.5 \mathrm{~h}$ at $55^{\circ} \mathrm{C}$ with $2 \mathrm{U}$ of restriction enzyme (Fermentas, Vilnius, Lithuania), and analyzed on a 3\% agarose gel. Digestion resulted in genotypes CC (75 and $19 \mathrm{bp}$ ), CT (94, 75, and $19 \mathrm{bp}$ ), and TT (94 bp, uncut product). For Sau3AI, an 1820-bp PCR product was digested overnight at $37^{\circ} \mathrm{C}$ with $3 \mathrm{U}$ of endonuclease (Fermentas) and analyzed on $2 \%$ agarose gel. Digestion resulted in genotypes $\mathrm{AA}(730,690$, and $400 \mathrm{bp}), \mathrm{AB}(730,690,400$, 
Table 1. PCR conditions.

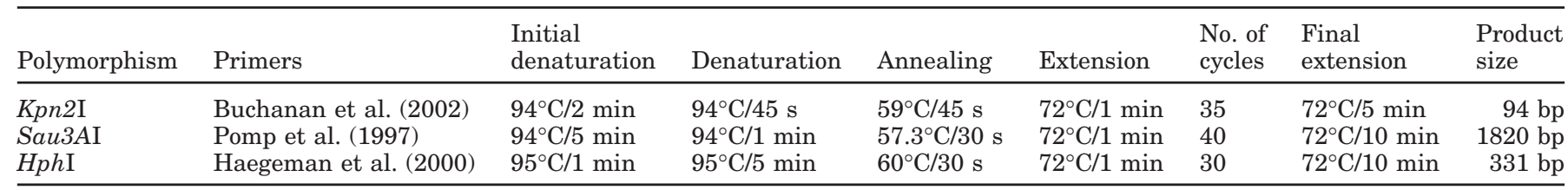

310 , and $90 \mathrm{bp}), \mathrm{BB}(730,690,310$, and $90 \mathrm{bp})$, and a rare AC polymorphism resulting from an additional restriction site (the 690-bp fragment was digested into 470- and 220-bp fragments). For HphI, a 331-bp PCR product was digested overnight at $37^{\circ} \mathrm{C}$ with $3 \mathrm{U}$ of the restriction enzyme (NewEngland BioLabs, Frankfurt, Germany), and analyzed on a $2 \%$ agarose gel. Digestion revealed 3 genotypes, CC (undigested, $331 \mathrm{bp),} \mathrm{CT} \mathrm{(331,}$ 311 , and $20 \mathrm{bp}$ ), and TT (311 and $20 \mathrm{bp}$ ).

All genotypes were distributed according to the Hardy-Weinberg law and the frequencies of the alleles were as follows. Kpn2I: $\mathrm{C}=0.54, \mathrm{~T}=0.46 ; H p h \mathrm{I}$ : $\mathrm{C}=$ $0.66, \mathrm{~T}=0.34$; and Sau3AI: $\mathrm{A}=0.86, \mathrm{~B}=0.11, \mathrm{C}=$ 0.03 . The effect of genotype on the breeding values of bulls for 5 traits was tested by analyzing least square means within the one-way ANOVA. The MULTTEST procedure of SAS (SAS, 1999) was used to allow for $P$ value adjustment by permutation.

The results showed that the $H p h \mathrm{I}$ polymorphism (the TT genotype) had an effect on the breeding values of yield traits (Table 2). Animals with the TT genotype had approximately $2 \times$ higher EBV for milk and protein yields (for both traits $P=0.006$ ). Fat yield for this genotype also tended to be higher $(P<0.1)$. The $H p h \mathrm{I}$ restriction site resulting in a change from alanine to valine is located at the conserved region of the $\beta$ helix of the leptin protein. Because alanine and valine have similar nonpolar aliphatic R-groups, the substitution should not affect the protein structure or binding to its receptor. This polymorphism should not, therefore, directly influence production traits, but may be linked with other unknown milk production QTL in the vicinity. No effect on fat and protein content suggests that differences in fat and protein yields are generally re- lated to increased milk yield. We did not find associations between the Kpn2I and Sau3AI polymorphisms and production traits, in contrast with the results published by Liefers et al. (2002). Liefers et al. (2002) did not find any effect of the $H p h \mathrm{I}$ polymorphism, although they pointed to Sau3AI as a possible marker for milk and protein yield. Similarly, Buchanan et al. (2003) demonstrated a strong influence of the Kpn2I polymorphism (the TT genotype) on milk and protein yield, which was not confirmed in this study. The presence of a rare C allele (Sau3AI) (associated with some cattle breeds, e.g., Gelbvieh, Simmental, and Angus; Pomp et al., 1997) was also related to fat and protein content in the Polish Black and White cattle (Zwierzchowski et al., 2002). Our studies do not support these relationships. Such discrepant results may be due to a number of factors, including the relatively small number of animals studied (117 bulls), population differences or breed composition, the small number of animals with the TT genotype (12), and the simple design of our experiment. On the other hand, the average reliability of bull proofs indicates a rather high number of daughters used in the genetic evaluation. In addition to genotype, many other factors influence milk yield and composition. These include environmental factors, the cow's age, lactation parity and stage, and the animal's health with special reference to the mammary gland (Mackle et al., 1998). Although many nongenetic factors are included in the genetic evaluation model, they may still interfere with the genetic component.

Pedigree analysis revealed that a group of 12 bulls genotyped as TT for $H p h \mathrm{I}$ had 2 common ancestors, of which one appeared in the third or fourth generation. The average relationship among these bulls was $6.75 \%$,

Table 2. Mean EBV (standard deviation) for production traits of bulls with different $H p h$ I genotypes. Values denote deviations from the official genetic base defined as the mean breeding values of cows born in 1995 .

\begin{tabular}{lllllll}
\hline Genotype & $\begin{array}{l}\text { No. of } \\
\text { bulls }\end{array}$ & $\begin{array}{l}\text { Milk yield } \\
(\mathrm{kg})\end{array}$ & $\begin{array}{l}\text { Fat yield } \\
(\mathrm{kg})\end{array}$ & $\begin{array}{l}\text { Protein yield } \\
(\mathrm{kg})\end{array}$ & $\begin{array}{l}\text { Fat content } \\
(\% \times 100)\end{array}$ & $\begin{array}{l}\text { Protein content } \\
(\% \times 100)\end{array}$ \\
\hline CC & 50 & $447.06(465.08)^{\mathrm{A}}$ & $19.37(16.01)^{\mathrm{a}}$ & $14.43(14.27)^{\mathrm{A}}$ & $1.67(25.04)$ & $-0.02(12.12)$ \\
CT & 55 & $511.77(454.88)^{\mathrm{A}}$ & $21.51(14.98)^{\mathrm{a}}$ & $14.48(13.14)^{\mathrm{A}}$ & $0.96(25.63)$ & $-3.97(9.59)$ \\
TT & 12 & $913.07(332.15)^{\mathrm{B}}$ & $31.33(16.23)^{\mathrm{b}}$ & $28.17(9.62)^{\mathrm{B}}$ & $-8.88(22.19)$ & $-0.62(12.20)$ \\
Probability & & 0.006 & 0.065 & 0.006 & 0.496 & 0.997 \\
\hline
\end{tabular}

${ }^{\mathrm{A}, \mathrm{B}}$ Means sharing a common (uppercase) superscript are not significantly different $(P<0.01)$; ${ }^{\mathrm{a}, \mathrm{b}}$ Tendency $(P<0.1)$. 
suggesting that these animals may have many genes in common. Further studies of pedigrees showed that the average relationship between all studied bulls was $4.99 \%$ and one bull (the common ancestor of the 12 TT bulls) contributed $18.4 \%$ to this average relationship. Such a close relationship makes it difficult to draw unambiguous conclusions. The contradictory results of the effect of the leptin gene polymorphisms on milk production may reflect the presence of population specific haplotypes and other unknown milk production QTL.

\section{ACKNOWLEDGMENTS}

This research was partly supported by the Polish State Committee for Scientific Research, Project KBN No. 6 P06D 01920.

\section{REFERENCES}

Ashwell, M. S., D. W. Heyen, T. S. Sonstegard, C. P. Van Tassel, Y. Da, P. M. VanRaden, M. Ron, J. I. Weller, and H. A. Lewin. 2004. Detection of quantitative trait loci affecting milk production, health, and reproductive traits in Holstein cattle. J. Diary. Sci. 87:468-475.

Buchanan, F. C., C. J. Fitzsimmons, A. G. Van Kessel, T. D. Thue, D. C. Winkelman-Sim, and S. M. Schmutz. 2002. Association of a missense mutation in the bovine leptin gene with carcass fat content and leptin mRNA levels. Genet. Sel. Evol. 34:105-116.
Buchanan, F. C., A. G. Van Kessel, C. Waldner, D. A. Christensen, B. Laarveld, and S. M. Schmutz. 2003. An association between a leptin single nucleotide polymorphism and milk and protein yield. J. Dairy Sci. 86:3164-3166.

Gonzalez, R. R., C. Simon, P. Caballero-Campo, R. Norman, D. Chardonnens, L. Devoto, and P. Bischof. 2000. Leptin and reproduction. Hum. Reprod. 6:290-300.

Haegeman, A., A. van Zaveren, and L. J. Peelman. 2000. New mutation in exon 2 of bovine leptin gene. Anim. Genet. 31:79.

Lagonigro, R., P. Wiener, F. Pilla, J. A. Woolliams, and J. L. Williams. 2003. A new mutation in the coding region of the bovine leptin gene associated with feed intake. Anim. Genet. 34:371-374.

Liefers, S. C., M. F. W. te Pas, R. F. Veerkamp, and T. van der Lende. 2002. Associations between leptin gene polymorphisms and production, live weight, energy balance, feed intake, and fertility in Holstein Heifers. J. Dairy Sci. 85:1633-1638.

Lindersson, M., L. Andersson-Eklund, D.-J. de Koning, A. Lunden, A. Maki-Tanila, and L. Andersson. 1998. Mapping of serum amylase-1 and quantitative trait loci for milk production traits to cattle chromosome 4. J. Dairy Sci. 81:1454-1461.

Mackle, T. R., A. M. Bryaant, S. F. Pertch, J. P. Hill, and M. Auldist. 1998. Nutritional influences on the composition of milk from cows of different protein genotype in New Zealand. J. Dairy Sci. 82:172-180.

Pomp, D., T. Zou, A. C. Clutter, and W. Barendse. 1997. Mapping of leptin to bovine chromosome 4 by linkage analysis of a PCR-based polymorphism. J. Anim. Sci. 75:1427.

SAS Online Doc, Version 8. 1999. SAS Institute, Inc., Cary, NC.

Silva, L. F. P., M. J. VandeHaar, M. S. Weber Nielsen, and G. W. Smith. 2002. Evidence for a local effect of leptin in bovine mammary gland. J. Dairy Sci. 85: 3277-3286.

Zwierzchowski, L., J. Krzyzewski, N. Strzalkowska, E. Siadkowska, and Z. Ryniewicz. 2002. Effects of polymorphism of growth hormone (GH), Pit-1, and leptin (LEP) genes, cow's age, lactation stage and somatic cell count on milk yield and composition of Polish Black and White cows. Anim. Sci. Pap. Rep. 20:213-227. 